\title{
Mixed Chimerism after Allogeneic Stem Cell Transplantation - Focus on Double Cord Blood Transplantation
}

\author{
Gertow Jens ${ }^{1,2}$, Stikvoort Arwen ${ }^{2}$, Watz Emma ${ }^{2,3}$, Mattsson Jonas ${ }^{1,2}$ and Uhlin Michael ${ }^{1,2 *}$ \\ ${ }^{1}$ Centre for Allogeneic Stem Cell Transplantation, Karolinska University Hospital, Sweden \\ ${ }^{2}$ Department of Laboratory Medicine, Division of Theurapetical Immunology, Karolinska Institute, Sweden \\ ${ }^{3}$ Department of Clinical Immunology and Transfusion Science, Karolinska University Hospital, Sweden
}

\begin{abstract}
Allogeneic hematopoietic Stem Cell Transplantation (ASCT) is well established as a curative treatment for many hematological malignancies and non-malignant disorders. The aim of ASCT in these diseases is to achieve sustained donor engraftment to fight leukemic cells in malignant disease, improve hematopoietic function, provide immune competence or normalize enzyme deficiency. Peripheral blood or bone marrow is commonly used to monitor engraftment after ASCT. The presence of mixed donor/recipient chimerism after transplantation, donor/donor chimerism after double cord blood transplantation can be used and interpreted differently based on the initial disease status. In patients with malignant diseases, chimerism is primarily used to detect early relapse but can also indicate threatening rejection. In individuals with non malignant disease, chimerism is merely used to monitor successful engraftment. After double cord blood transplantation, the unique situation with two existing donor immune systems can occur. Most often one of the immune systems rapidly succumbs with one immune system prevailing, but in certain situations mixed donor/donor chimerism can exist for prolonged periods. This review describes the importance of mixed chimerism and the possible interpretation after ASCT in patients with both malignant and non-malignant diseases. It also focuses specifically on the situation and mechanisms donor/ donor chimerism after double cord blood transplantation.
\end{abstract}

Keywords: Mixed chimerism; Allogeneic; Stem cell transplantation

\section{Allogeneic Stem Cell Transplantation}

Allogeneic Stem Cell Transplantation (SCT) is used as a curative treatment for leukemic malignancies, genetic defects in metabolism or immune function and certain solid tumors [1-3]. Historically SCT was performed with bone marrow and subsequently peripheral blood as stem cell source [4]. Two decades ago cord blood was added as a third possible source [5].

The post-transplant management of allogeneic SCT is associated with several lethal complications. Most complications are associated with compromised immune function during the neutropenic and later leukopenic phase, or are due to the action of, or interactions between, the host and the donor immune systems [6-9]. Additionally, the decrease in immune function post transplant often results in opportunistic viral, bacterial and/or fungal infections $[7,10,11]$. Due to these complications the immunosuppressive management must be closely monitored in order not to unnecessarily extend or worsen this crucial period $[12,13]$. However, if the level of immunosuppression is too low, rejection and increased Graft Versus Host Disease (GVHD) frequencies might be unwanted consequences [14].

Infections can be monitored and fought with standard antimicrobial regiments, common in many hospital routines, while rejection and GVHD demand more specialized immunological methods and therapies [15-17].

\section{Graft Versus Leukaemia as an Immunological Tool after SCT}

Already two decades ago, the use of Donor Lymphocyte Infusions (DLI) was initiated to treat threatening relapse of the underlying malignant disease after SCT by increasing the Graft Versus Leukaemia effect (GVL) [18-20]. The GVL effect is mediated by donor-derived allogeneic $\mathrm{T}$ cells directly attacking the leukemic cells [2]. This advantageous effect was elegantly described by Horowitz et al. [21] who observed that patients who received identical twin transplants had an increased probability of relapse compared with allograft recipients. It was further shown that if $\mathrm{T}$ cells were depleted this risk was once again increased. Unfortunately this beneficial GVL effect is most often associated with an elevated risk for Graft Versus Host Disease (GVHD), where allogeneic $\mathrm{T}$ cells attack cells of non-malignant origin in the recipient $[16,21]$.

Initially all SCT patients received a Myeloablative pre-Conditioning (MAC). The conditioning treatment has two major aims: reduce the tumour burden (when the disease is neoplastic) and eliminate the recipient's immune system, in order to allow engraftment of new stem cells. MAC involves heavy chemotherapy and irradiation leaving the patient fully dependent on the new, engrafted hematopoietic stem cells. The severe toxic effects associated with this treatment have limited the use of SCT on elderly and seriously ill patients [22,23].

In the past two decades two changes have occurred in conditioning regimens in order to remedy this: the introduction of Fludarabine and dose reductions of the alkylating agents or Total Body Irradiation (TBI) $[24,25]$. These regimens were specifically designed for patients ineligible for MAC, either because of age or due to the presence of co-morbidities $[26,27]$. By reducing the conditioning intensity, the benefit of allogeneic SCT would generally come from a graft-versus-malignancy effect,

*Corresponding author: Michael Uhlin, Centre for Allogeneic Stem Cell Transplantation B87, Karolinska University Hospital Huddinge, SE-14186 Stockholm, E-mail: Michael.uhlin@ki.se

Received January 16, 2012; Accepted February 03, 2012; Published February 09, 2012

Citation: Jens G, Arwen S, Emma W, Jonas M, Michael U (2012) Mixed Chimerism after Allogeneic Stem Cell Transplantation - Focus on Double Cord Blood Transplantation. J Blood Disord Transfus S1:006. doi:10.4172/2155-9864.S1-006

Copyright: @ 2012 Jens G, et al. This is an open-access article distributed under the terms of the Creative Commons Attribution License, which permits unrestricted use, distribution, and reproduction in any medium, provided the original author and source are credited. 
rather than from the cyto-reductive effect of the conditioning regimen $[28,29]$. These modified regimens have been referred to as Reduced Intensity Conditioning (RIC) [30,31]. Today approximately $50 \%$ of all transplants are performed with reduced intensity regimens [32,33].

After a successful ASCT, the patient/recipient usually adopts the donor hematopoietic system and becomes a full donor chimera. However, in some cases after ASCT, recipient hematopoietic cells remain and the patient instead becomes a mixed chimera. A patient is considered to be a mixed chimera if 5-95\% of its hematopoietic cells are of donor origin [34]. Some patients are only mixed chimeras for certain subsets, e.g. NK cells or erythrocytes [17,35,36]. Depending on treatment prior to ASCT, patients are more inclined to become either mixed chimeras or donor chimeras. In many situations it may be informative and even crucial to evaluate the development of donor chimerism after SCT. For example, it could allow early detection of rejection of the new hematopoietic system, where the chimerism analysis would indicate a rising percentage of recipient cells in bone marrow or peripheral blood [15,37]. This is also true for detection of early relapse where an increasing amount of recipient cells in the cell lineage with the same origin as the leukemia is observed [38-40].

\section{Chimerism Analysis after Stem Cell Transplantation}

Since chimerism analyses were first performed, many different methods have been developed and implemented all following the same basic principle of analyzing differences in polymorphic markers in the genome and their products between the recipient and the donor. The wide clinical use for these analyses came when PCR methods were developed in the 1990s. Different methods have been used during the last 20 years (reviewed in [17]) but today most modern clinical immunology laboratories use either characterization of Short Tandem Repeat (STR) markers by fluorescent labelling of the PCR primers and resolution of products with capillary electrophoresis or new real-time PCR techniques aimed at the amplification of 'SingleNucleotide Polymorphisms' (SNPs) [41,42]. SNPs are bi-allelic variants that differ from each other only at a single nucleotide and occur on average very frequently in the human genome. In contrast to earlier PCR based methods, where virtually all donor/recipients pairs could be characterized, with 8-10 markers, with the real time based method much more markers $(>15)$ are needed in order to reach the same level of information. Real-time PCR also suffers from less quantitative accuracy compared to the STR systems when high levels of recipient product are detected. However, the real-time PCR method is at least one log of magnitude more sensitive than the STR-based method and therefore more suited to detect low levels of leukemia cells.

\section{The Different Roles of Mixed Chimerism after Allogeneic Stem Cell Transplantation - The Importance of Circumstances}

Historically, mixed chimerism post-SCT was considered to be detrimental for the recipient and always a warning sign for either rejection or malignant relapse [17]. However, this view is today more nuanced and it has become clear that donor and recipient hematopoietic cells can, in certain situations, coexist for prolonged periods [43-45].

\section{Mixed Donor Recipient Chimerism after Allogeneic Stem Cell Transplantation - Malignant Diseases}

Using current chimerism detection methods, it is impossible to determine whether the emergence of reappearing or persisting recipient cells post-SCT is a mere manifestation for survival of normal healthy hematopoietic cells, leukemic cells or both. In patients with e.g. Chronic Myeloid Leukemia (CML) several studies have demonstrated that the occurrence of recipient cells precedes a relapse [46-48]. Hence, mixed chimerism is considered to be associated with a reduced existing GVL effect in this patient category.

In patients with acute leukemia the situation is not as clear-cut. Some studies could show that mixed chimerism after SCT had no correlation with malignant relapse $[49,50]$ while others found the opposite $[51,52]$. These differences conflicting results can most likely be attributed to differences in study populations. In a recent study in children with AML, patients with mixed chimerism were offered immunotherapeutic treatment solely based on chimerism data. Half of these patients could be turned into full Donor Chimerism (DC) without relapse. Of nontreated patients with Mixed Chimerism (MC) all relapsed [53]. These results are also supported by a larger study where patients with acute leukemia and myelodysplastic syndrome showed a 3-year survival of $42 \%$ if DLI treatment was given because of molecular evidence of mixed chimerism, compared to $16 \%$ in hematologic relapse [20].

In another study focused on children with Acute Lymphocytic Leukemia (ALL), it was shown that treatment of threatening relapse, as defined by an emerging MC pattern could be treated by immunotherapeutic measurements [54]. It is important to mention that due to the low sensitivity of the chimerism assays (>1-5\%) in many cases immune theurapetical intermission may be too late [55].

What is universal for many of these studies is the importance of serial chimerism measurements $[39,40,45]$. Several consecutive measurements are required to disregard natural fluctuations, especially when evaluating the possibility to prevent relapse by pre-emptive immunotherapy on the basis of chimerism analysis in patients with acute leukemia. Proposed guidelines from different centers are weekly or bi weekly until 200 days post transplantation $[17,38]$.

\section{Mixed Donor Recipient Chimerism after Allogeneic Stem Cell Transplantation - Non-Malignant Diseases}

As stated before, SCT is the cure to a variety of non-malignant diseases, varying from hemoglobinopathies, e.g. thalassemia and sickle cell diseases, to diseases such as Severe Aplastic Anemia (SAA), leukodystrophies and Wiskott-Aldrich Syndrome (WAS) [56]. For all of these diseases, incidences of mixed chimerism after SCT have been reported.

While the occurrence of MC might be associated with relapse in patients with malignant diseases, there is no fear of this happening in patients with non-malignant diseases. In many cases the implementation of a state of mixed chimerism is mostly sufficient to improve the patient's disease status and well-being and due to this physicians tend to have a greater tolerance for MC. As a result, more literature exists on the phenomenon of mixed chimerism in non-malignant patients than in malignant patients after SCT.

For non-malignant patients, the first two years post-SCT are considered the most critical regarding chimerism status with most individuals either rejecting the graft or becoming full donor chimeras during that time [57]. Due to this, most patients with mixed chimerism are not followed up for longer than 1 to 2 years post-SCT [17,58-60].

During this initial period ( $<2$ years) some studies have shown that a high mixed chimerism of over $30 \%$ recipient leads to increased risk of graft rejection [61-63] while others have failed to confirm this $[60,64]$. Only a very small portion of patients have been reported to still 
be mixed chimeras after this period $[43,58]$. Historically, patients with stable mixed chimerism have been pushed into full donor chimerism via the administration of DLI. However, more current studies, indicate that this may not be necessary for all mixed chimerism in non-malignant patients post-SCT $[62,65]$. If these observations hold true, the need for DLI would decrease in this patient category and hence the risk of GVHD would putatively be lowered. One case study on a patient with stable mixed chimerism several years post SCT has shown no obvious negative side effects. This patient still remains disease free and has not rejected, even after a prolonged period of time [43].

What happens in patient with stable mixed chimerism is unknown. It is plausible that either the immune system of the recipient or donor is pre-dominant, but this has of yet not been confirmed in studies $[62,65]$.

\section{Mixed Donor/Donor Chimerism after Double Cord Blood Transplantation}

During the early nineties, transplantation centers began utilizing unrelated umbilical cord blood as an alternative stem cell source for patients lacking an HLA-matched adult donor [66-68]. As the cell dose of an umbilical cord is limited and often relatively low historically the majority of patients enrolled were children $[69,70]$. To make cord blood an option also for adult patients Double Cord Blood Transplantation (DCBT) was introduced [71]. In this treatment modality, used for patients with both malignant and non-malignant underlying diseases [72], two matched or par 7 tially matched cord blood units are cotransplanted.

Even though a mixed donor/donor chimerism is commonly seen during the first few weeks after transplantation [71,73,74], one of the $\mathrm{CB}$ units generally prevails and the sustained hematopoiesis is derived from a single $\mathrm{CB}$ unit [75-77]. However, in rare instances a long-term, stable donor/donor chimerism develops after double cord blood transplantation. To our knowledge, eight published studies have described this phenomenon at day 60 or more after transplantation $[45,75,78-83]$ and for five of the described patients in these studies the double chimerism was apparent for over one year post-transplantation [45,81-83]. Thus, out of at least a thousand DCBTs performed to date [72], only a handful of stable donor/donor chimeras have been described.

Understanding the factors determining engraftment of cord blood units after DCBT may have implications for graft-selection, where, for example, two units with high probability of long-term engraftment could be chosen. Several studies have therefore tried to elucidate predictive factors for unit predominance [71,75,77,84-88], which rationally are the same as knowing the factors generating mixed donor/ donor chimerism.

Since stem cell dose is determinative in choosing DCBT over single unit cord blood transplantation, one would think that the CD34+ cell dose of a cord blood unit is a predictive factor for unit predominance. Studies of this notion have had conflicting results. Whereas both Verneris et al. [89] in a study of 93 patients as well as Ramirez et al. [84] in a study of 262 patients with hematologic malignancies found no correlation between CD34+ dose and unit predominance, Avery et al. [77] did indeed find such a correlation in a study of 84 patients $[75,77,84]$. Of course, high CD34+ cell content is of no use if the progenitor cells are not viable. In the same study, Avery et al. [77] showed that the percentage of viable CD34+ was associated with engraftment and unit dominance. This finding has been endorsed by a prospective study where cord blood units with high fraction of viable cells were co-transplanted with a unit of low viability. In 15 out of 16 cases, the high CD34+ viability unit engrafted [85].

Importantly, the cord blood graft does not only contain progenitor cells. Verneris et al. [89] suggested in 2005 that a higher CD3+ cell dose in a cord blood unit was associated with becoming predominant [71]. Although refuted by the same group in a larger study [75], this suggestion has now been supported in both a myeloablative and RIC setting $[77,84]$.

The observations that $\mathrm{CD} 3+$ cell dose is a predicting factor for predominance has spurred the hypothesis that the "winning" unit develops an immune reaction towards the other unit and rejects it. Corroborating this hypothesis are discoveries that DCBTs have increased GVHD and lower relapse rates compared to single CBTs $[75,89]$ and that patients with mixed donor/donor chimerism after RIC still can develop chronic GVHD [88]. Furthermore, a human/ murine xenotransplantation model showed that after positive selection of CD34+ cells and subsequent DCBT, mixed donor/donor chimerism was very frequent. When, however, CD34- cells from one $\mathrm{CB}$ unit were infused to the transplanted animal, single-unit dominance of that same $\mathrm{CB}$ unit was induced [86].

In a DCBT setting, immune interactions could develop between the two cord blood units as well as between the units and the recipient. The degree of HLA match between the two units and between units and recipient may therefore play a role in the engraftment process. Conflicting results have been reported here. In the RIC setting, Brunstein et al. [75] found no correlation between HLA match and unit predominance, whereas a more recent study indeed did show a correlation between these parameters [75,84].

In the myeloablative setting, donor-recipient HLA disparity had no influence on engraftment, but although unit-unit HLA match also did not affect engraftment, closely matched units were more likely to co-engraft initially [77]. This finding is in line with the hypothesis of immune interactions between the two cord blood units, since a close HLA-match could indicate a tolerance for one another.

Compelling evidence for a graft-versus-graft interaction came when Gutman et al. [87] showed that in 9 out of 10 patients with single unit dominance, a significant subset of CD8+ T cells derived from the engrafting unit produced interferon (IFN) $-\gamma$ in response to the nonengrafting unit [87]. Moreover, in three patients with persistent mixed donor/donor chimerism no significant IFN- $\gamma$ producing cells were detected after similar stimulations. These cells were however detected only transiently after transplantation and the antigens to which the $\mathrm{CD} 8+\mathrm{T}$ cells respond remain unknown. An interesting in vitro model system based on a two-way Mixed Lymphocyte Culture (MLC) was recently presented by Moretta et al. [90] as a tool to identify the potentially predominant $\mathrm{CB}$ unit even before DCBT. As in the study by Gutman, it was proposed that the dominant CB unit to a higher degree developed allo-antigen induced cytotoxicity against the other graft.

The described CD8+ $\mathrm{T}$ cells should probably not be held accountable as the only cause of rejection, partly because T cells are not the only cells responding to HLA molecules. Natural Killer (NK) cell function is to a high extent regulated by inhibitory and activating Killer cell Immunoglobulin-like Receptors (KIRs) that recognize certain HLA molecules. The majority of KIRs respond to just two known epitope groups of HLA-C, but also HLA-A, -B and -G may function as ligands [91]. Recipient-donor KIR-mismatch has been associated with less relapse and better overall survival in single cord blood transplantations [92]. Whether this finding translates into graft-graft immune reaction 
in the DCBT setting has not yet been investigated. However, our group observed a complete HLA-C match between units in a study of the phenotypes and functionality of the two immune systems in two patients with long-term stable donor/donor chimerism [44]. Patients in this study were conditioned with high-dose Anti-Thymocyte Globulin (ATG) depleting the grafts of $\mathrm{T}$ cells in vivo [93] and putatively reducing the potential for $\mathrm{T}$ cell mediated rejection in any direction for a prolonged time. The absence of T cells could allow NK cells to expand more freely and in a KIR/HLA-C mismatched situation lead to unit rejection, or, as in the described situation of HLA-C match lead to tolerance.

However, since the use of ATG or other forms of T cell depletion method was not mentioned in but a few of the eight referred publications of mixed donor/donor chimerism $[45,75,78]$. T cell depletion does not seem to be required for the development of a double chimera.

Our group has also demonstrated that, the two cord blood units had in a mixed donor chimera had comparable $\mathrm{T}$ cell receptor repertoires but were phenotypically and functionally different [44]. In both patients one unit occupied a larger part of the immune system with $\mathrm{T}$ and NK cells responding to stimuli by producing cytokines in a manner similar to an immune system developed after single unit dominance. In contrast, the other unit occupied a minor part of the total immune system and was more non-responsive and accordingly had a more naïve $\mathrm{T}$ cell phenotype. Consequently, in comparison to patients with single unit dominance, the two systems together in the patients with mixed donor/donor chimerism had a more naïve phenotype and a decreased functionality. Thus, while this study contains only two patients, having a double chimerism is probably not an advantage compared to having single unit dominance. On the other hand, some double chimeras described have been without complications still up to 66 months after transplantation $[45,83]$.

Even in a long-term mixed chimerism situation the immune systems are successful to varying degrees in repopulating their host [44] and in one case dominance reversion has been observed as late as 133 days post-transplantation [81]. These findings could be a reflection of immune reactions between the two cord blood grafts as well as with the recipient in these patients. Although contested by the findings that grafts of mixed chimeras have no significant IFN- $\gamma$ production in response to one another [87], the intensity of the immune reactions could putatively be there but not strong enough for either graft rejection or detection by flow cytometry.

Another plausible explanation for unit predominance is yet unresolved intrinsic properties of the CD34+ progenitor cells leading to e.g. diverse bone marrow homing potential. Support for this comes from ex vivo expansion studies showing extremely variable proliferative potential of progenitor cells between cord blood units [87]. Likewise, our group has studied ex vivo proliferation potential of cord blood $\mathrm{CD} 3+\mathrm{T}$ cells and observed huge differences ranging from 0 to over thousand fold expansion in a matter of days [94].

As seen, several possible and probable factors lead to the development of a mixed donor/donor chimerism. Future studies will reveal if graft selection can be improved and will shed light on whether mixed donor/donor chimerism should be strived for, eliminated or be left unaddressed.

\section{References}

1. Ringdén O, Remberger M, Svahn BM, Barkholt L, Mattsson J, et al. (2006) Allogeneic hematopoietic stem cell transplantation for inherited disorders: experience in a single center. Transplantation 81: 718-725.
2. Ringden $O$, Karlsson $H$, Olsson $R$, Omazic B, Uhlin M (2009) The allogeneic graft-versus-cancer effect. Br J Haematol 147: 614-633.

3. Childs RW, Barrett J (2004) Nonmyeloablative allogeneic immunotherapy for solid tumors. Annu Rev Med 55: 459-475.

4. Korbling M, Freireich EJ (2011) Twenty-five years of peripheral blood stem cell transplantation. Blood 117: 6411-6416.

5. Gluckman E, Broxmeyer HA, Auerbach AD, Friedman HS, Douglas GW, et al. (1989) Hematopoietic reconstitution in a patient with Fanconi's anemia by means of umbilical-cord blood from an HLA-identical sibling. N Engl J Med 321 1174-1178.

6. Perez L, Anasetti C, Pidala J (2011) Have we improved in preventing and treating acute graft-versus-host disease? Curr Opin Hematol 18: 408-413.

7. Hiemenz JW (2009) Management of infections complicating allogeneic hematopoietic stem cell transplantation. Semin Hematol 46: 289-312.

8. Holler E (2009) The role of innate immunity in graft-versus-host disease and complications following allogeneic stem cell transplant. Biol Blood Marrow Transplant 15: 59-61.

9. Choi SW, Levine JE, Ferrara JL (2010) Pathogenesis and management of graft-versus-host disease. Immunol Allergy Clin North Am 30: 75-101.

10. Sparrelid E, Hagglund $H$, Remberger $M$, Ringden $O$, Lonnqvist $B$, et al. (1998) Bacteraemia during the aplastic phase after allogeneic bone marrow transplantation is associated with early death from invasive fungal infection. Bone Marrow Transplant 22: 795-800.

11. Blennow O, Remberger M, Klingspor L, Omazic B, Fransson K, et al. (2010) Randomized PCR-based therapy and risk factors for invasive fungal infection following reduced-intensity conditioning and hematopoietic SCT. Bone Marrow Transplant 45: 1710-1718.

12. Remberger M, Mattsson J, Svahn BM, Ringden O (2008) Using reduced intensity conditioning and HLA-identical sibling donors, antithymocyte globulin increases the risk of relapse, which can be overcome by a high stem cell dose. Bone Marrow Transplant 42: 769-771.

13. Malard F, Szydlo RM, Brissot E, Chevallier P, Guillaume T, et al. (2010) Impact of cyclosporine-A concentration on the incidence of severe acute graft-versushost disease after allogeneic stem cell transplantation. Biol Blood Marrow Transplant 16: 28-34

14. Remberger M, Mattsson J, Hassan Z, Karlsson N, LeBlanc K, et al. (2008) Risk factors for acute graft-versus-host disease grades II-IV after reduced intensity conditioning allogeneic stem cell transplantation with unrelated donors: a single centre study. Bone Marrow Transplant 41: 399-405

15. Dubovsky J, Daxberger H, Fritsch G, Printz D, Peters C, et al. (1999) Kinetics of chimerism during the early post-transplant period in pediatric patients with malignant and non-malignant hematologic disorders: implications for timely detection of engraftment, graft failure and rejection. Leukemia 13: 2059, 2060 2069

16. Kolb HJ (2008) Graft-versus-leukemia effects of transplantation and donor lymphocytes. Blood 112: 4371-4783.

17. Bader P, Niethammer D, Willasch A, Kreyenberg H, Klingebiel T (2005) How and when should we monitor chimerism after allogeneic stem cell transplantation? Bone Marrow Transplant 35: 107-119.

18. Bader P, Willasch A, Klingebiel T (2008) Monitoring of post-transplant remission of childhood malignancies: is there a standard? Bone Marrow Transplant 2 S31-S34.

19. Kolb HJ, Schattenberg A, Goldman JM, Hertenstein B, Jacobsen N, et al. (1995) Graft-versus-leukemia effect of donor lymphocyte transfusions in marrow grafted patients. Blood 86: 2041-2050.

20. Sairafi D, Remberger $M$, Uhlin $M$, Ljungman $P$, Ringden $O$, et al. (2010) Leukemia lineage-specific chimerism analysis and molecular monitoring improve outcome of donor lymphocyte infusions. Biol Blood Marrow Transplan 16: $1728-1737$

21. Horowitz MM, Gale RP, Sondel PM, Goldman JM, Kersey J, et al. (1990) Graftversus-leukemia reactions after bone marrow transplantation. Blood 75: 555562 
22. Robin M, Guardiola P, Dombret H, Baruchel A, Esperou H, et al. (2003) Allogeneic bone marrow transplantation for acute myeloblastic leukaemia in remission: risk factors for long-term morbidity and mortality. Bone Marrow Transplant 31: 877-887

23. de Lima M, Giralt S (2006) Allogeneic transplantation for the elderly patient with acute myelogenous leukemia or myelodysplastic syndrome. Semin Hematol 43: $107-117$

24. Slavin S, Nagler A, Naparstek E, Kapelushnik Y, Aker M, et al. (1998) Nonmyeloablative stem cell transplantation and cell therapy as an alternative to conventional bone marrow transplantation with lethal cytoreduction for the treatment of malignant and nonmalignant hematologic diseases. Blood 91: 756-763.

25. Uzunel M, Remberger M, Sairafi D, Hassan Z, Mattsson J, et al. (2006) Unrelated versus related allogeneic stem cell transplantation after reduced intensity conditioning. Transplantation 82: 913-919.

26. Champlin R, Khouri I, Anderlini P, Gajewski J, Kornblau S, et al. (2001) Nonmyeloablative preparative regimens for allogeneic hematopoietic transplantation. Bone Marrow Transplant 2: S13-S22.

27. Sayer HG, Kroger M, Beyer J, Kiehl M, Klein SA, et al. (2003) Reduced intensity conditioning for allogeneic hematopoietic stem cell transplantation in patients with acute myeloid leukemia: disease status by marrow blasts is the strongest prognostic factor. Bone Marrow Transplant 31: 1089-1095.

28. Baron F, Storb R (2006) Allogeneic hematopoietic cell transplantation following nonmyeloablative conditioning as treatment for hematologic malignancies and inherited blood disorders. Mol Ther 13: 26-41.

29. Barrett AJ, Savani BN (2006) Stem cell transplantation with reduced-intensity conditioning regimens: a review of ten years experience with new transplant concepts and new therapeutic agents. Leukemia 20: 1661-1672.

30. Ringden O, Labopin M, Ehninger G, Niederwieser D, Olsson R, et al. (2009) Reduced intensity conditioning compared with myeloablative conditioning using unrelated donor transplants in patients with acute myeloid leukemia. J Clin Oncol 27: 4570-4577.

31. de Lima M, Anagnostopoulos A, Munsell M, Shahjahan M, Ueno N, et al. (2004) Nonablative versus reduced-intensity conditioning regimens in the treatment of acute myeloid leukemia and high-risk myelodysplastic syndrome: dose is relevant for long-term disease control after allogeneic hematopoietic stem cell transplantation. Blood 104: 865-872.

32. Marsh RA, Jordan MB, Filipovich AH (2011) Reduced-intensity conditioning haematopoietic cell transplantation for haemophagocytic lymphohistiocytosis: an important step forward. Br J Haematol 154: 556-563.

33. Remberger M, Ackefors M, Berglund S, Blennow O, Dahllof G, et al. (2011) Improved survival after allogeneic hematopoietic stem cell transplantation in recent years. A single-center study. Biol Blood Marrow Transplant 17: 16881697.

34. Baron F, Sandmaier BM (2006) Chimerism and outcomes after allogeneic hematopoietic cell transplantation following nonmyeloablative conditioning. Leukemia 20: 1690-1700.

35. Svenberg P, Mattsson J, Ringden O, Uzunel M (2009) Allogeneic hematopoietic SCT in patients with non-malignant diseases, and importance of chimerism. Bone Marrow Transplant 44: 757-763.

36. Andreani M, Testi M, Battarra M, Lucarelli G (2011) Split chimerism between nucleated and red blood cells after bone marrow transplantation for haemoglobinopathies. Chimerism 2: 21-22

37. Gyger M, Baron C, Forest L, Lussier P, Lagace F, et al. (1998) Quantitative assessment of hematopoietic chimerism after allogeneic bone marrow transplantation has predictive value for the occurrence of irreversible graft failure and graft-vs.-host disease. Exp Hematol 26: 426-434.

38. Mattsson J, Uzunel M, Tammik L, Aschan J, Ringden O (2001) Leukemia lineage-specific chimerism analysis is a sensitive predictor of relapse in patients with acute myeloid leukemia and myelodysplastic syndrome after allogeneic stem cell transplantation. Leukemia 15: 1976-1985.

39. Ramirez M, Diaz MA, Garcia-Sanchez F, Velasco M, Casado F, et al. (1996)
Chimerism after allogeneic hematopoietic cell transplantation in childhood acute lymphoblastic leukemia. Bone Marrow Transplant 18: 1161-1165.

40. Bader P, Holle W, Klingebiel T, Handgretinger R, Benda N, et al. (1997) Mixed hematopoietic chimerism after allogeneic bone marrow transplantation: the impact of quantitative PCR analysis for prediction of relapse and graft rejection in children. Bone Marrow Transplant 19: 697-702.

41. Beck O, Seidl C, Lehrnbecher T, Kreyenberg H, Schwabe D, et al. (2006) Quantification of chimerism within peripheral blood, bone marrow and purified leukocyte subsets: comparison of singleplex and multiplex PCR amplification of short tandem repeat (STR) loci. Eur J Haematol 76: 237-244.

42. Willasch A, Schneider G, Reincke BS, Shayegi N, Kreyenberg H, et al. (2007) Sequence polymorphism systems for quantitative real-time polymerase chain reaction to characterize hematopoietic chimerism-high informativity and sensitivity as well as excellent reproducibility and precision of measurement Lab Hematol 13: 73-84.

43. Saito AM, Chiba S, Ogawa S, Kanda Y, Hirai H, et al. (2007) Long-term sustained mixed chimerism after allogeneic stem cell transplantation in a patient with severe aplastic anemia. Intern Med 46: 1923-1926.

44. Gertow J, Berglund S, Okas M, Uzunel M, Berg L, et al. (2010) Characterization of long-term mixed donor-donor chimerism after double cord blood transplantation. Clin Exp Immunol 162: 146-155.

45. Berglund S, Okas M, Gertow J, Uhlin M, Mattsson J (2009) Stable mixed donordonor chimerism after double cord blood transplantation. Int J Hematol 90: 526531.

46. Mackinnon S, Barnett L, Heller G, O'Reilly RJ (1994) Minimal residual disease is more common in patients who have mixed T-cell chimerism after bone marrow transplantation for chronic myelogenous leukemia. Blood 83: 3409-3416.

47. Gardiner N, Lawler M, O’Riordan J, DeArce M, Humphries P, et al. (1997) Persistent donor chimaerism is consistent with disease-free survival following BMT for chronic myeloid leukaemia. Bone Marrow Transplant 20: 235-241.

48. Levenga $H$, Woestenenk R, Schattenberg AV, Maas F, Jansen JH, et al. (2007) Dynamics in chimerism of $T$ cells and dendritic cells in relapsed CML patients and the influence on the induction of alloreactivity following donor lymphocyte infusion. Bone Marrow Transplant 40: 585-592.

49. Formankova R, Sedlacek P, Krskova L, Rihova H, Sramkova L, et al. (2003) Chimerism-directed adoptive immunotherapy in prevention and treatment of post-transplant relapse of leukemia in childhood. Haematologica 88: 117-118.

50. Gorczynska E, Turkiewicz D, Toporski J, Kalwak K, Rybka B, et al. (2004) Prompt initiation of immunotherapy in children with an increasing number of autologous cells after allogeneic HCT can induce complete donor-type chimerism: a report of 14 children. Bone Marrow Transplant 33: 211-217.

51. Schaap N, Schattenberg A, Mensink E, Preijers F, Hillegers M, et al. (2002) Long-term follow-up of persisting mixed chimerism after partially $T$ cell-depleted allogeneic stem cell transplantation. Leukemia 16: 13-21.

52. Choi SJ, Lee KH, Lee JH, Kim S, Chung HJ, et al. (2000) Prognostic value of hematopoietic chimerism in patients with acute leukemia after allogeneic bone marrow transplantation: a prospective study. Bone Marrow Transplant 26: 327-332.

53. Rettinger E, Willasch AM, Kreyenberg H, Borkhardt A, Holter W, et al. (2011) Preemptive immunotherapy in childhood acute myeloid leukemia for patients showing evidence of mixed chimerism after allogeneic stem cell transplantation. Blood 118: 5681-5688.

54. Bader P, Kreyenberg H, Hoelle W, Dueckers G, Kremens B, et al. (2004) Increasing mixed chimerism defines a high-risk group of childhood acute myelogenous leukemia patients after allogeneic stem cell transplantation where pre-emptive immunotherapy may be effective. Bone Marrow Transplant 33: $815-821$

55. Bader P, Kreyenberg H, Hoelle W, Dueckers G, Handgretinger R, et al. (2004) Increasing mixed chimerism is an important prognostic factor for unfavorable outcome in children with acute lymphoblastic leukemia after allogeneic stemcell transplantation: possible role for pre-emptive immunotherapy? J Clin Oncol 22: $1696-1705$ 
56. Gaziev J, Lucarelli G (2003) Stem cell transplantation for hemoglobinopathies Curr Opin Pediatr 15: 24-31.

57. Hill RS, Petersen FB, Storb R, Appelbaum FR, Doney K, et al. (1986) Mixed hematologic chimerism after allogeneic marrow transplantation for severe aplastic anemia is associated with a higher risk of graft rejection and a lessened incidence of acute graft-versus-host disease. Blood 67: 811-816.

58. Moratto D, Giliani S, Bonfim C, Mazzolari E, Fischer A, et al. (2011) Long-term outcome and lineage-specific chimerism in 194 patients with Wiskott-Aldrich syndrome treated by hematopoietic cell transplantation in the period 19802009: an international collaborative study. Blood 118: 1675-1684.

59. Nesci S, Manna M, Andreani M, Fattorini P, Graziosi G, et al. (1992) Mixed chimerism in thalassemic patients after bone marrow transplantation. Bone Marrow Transplant 10: 143-146.

60. Li CK, Chik KW, Tsang KS, Pong H, Shing MM, et al. (2002) Mixed chimerism after bone marrow transplantation for thalassemia major. Haematologica 87 : 781-782.

61. Lawler M, McCann SR, Marsh JC, Ljungman P, Hows J, et al. (2009) Serial chimerism analyses indicate that mixed haemopoietic chimerism influences the probability of graft rejection and disease recurrence following allogeneic stem cell transplantation (SCT) for severe aplastic anaemia (SAA): indication for routine assessment of chimerism post SCT for SAA. Br J Haematol 144 933-945.

62. McCann SR, Crampe M, Molloy K, Lawler M (2005) Hemopoietic chimerism following stem cell transplantation. Transfus Apher Sci 32: 55-61.

63. Amrolia PJ, Vulliamy T, Vassiliou G, Lawson S, Bryon J, et al. (2001) Analysis of chimaerism in thalassaemic children undergoing stem cell transplantation. $\mathrm{Br}$ J Haematol 114: 219-225

64. Lisini D, Zecca M, Giorgiani G, Montagna D, Cristantielli R, et al. (2008) Donor/ recipient mixed chimerism does not predict graft failure in children with betathalassemia given an allogeneic cord blood transplant from an HLA-identical sibling. Haematologica 93: 1859-1867.

65. Walters MC, Patience M, Leisenring W, Rogers ZR, Aquino VM, et al. (2001) Stable mixed hematopoietic chimerism after bone marrow transplantation for sickle cell anemia. Biol Blood Marrow Transplant 7: 665-673.

66. Ringden O, Okas M, Uhlin M, Uzunel M, Remberger M, et al. (2008) Unrelated cord blood and mismatched unrelated volunteer donor transplants, two alternatives in patients who lack an HLA-identical donor. Bone Marrow Transplant 42: 643-648

67. Kurtzberg J, Laughlin M, Graham ML, Smith C, Olson JF, et al. (1996) Placental blood as a source of hematopoietic stem cells for transplantation into unrelated recipients. N Engl J Med 335: 157-166.

68. Rocha V, Gluckman E (2006) Clinical use of umbilical cord blood hematopoietic stem cells. Biol Blood Marrow Transplant 12: 34-41.

69. Rocha V, Wagner JE Jr, Sobocinski KA, Klein JP, Zhang MJ, et al. (2000) Graft-versus-host disease in children who have received a cord-blood or bone marrow transplant from an HLA-identical sibling. Eurocord and International Bone Marrow Transplant Registry Working Committee on Alternative Donor and Stem Cell Sources. N Engl J Med 342: 1846-1854.

70. Rubinstein P, Carrier C, Scaradavou A, Kurtzberg J, Adamson J, et al. (1998) Outcomes among 562 recipients of placental-blood transplants from unrelated donors. N Engl J Med 339: 1565-1577.

71. Barker JN, Weisdorf DJ, DeFor TE, Blazar BR, McGlave PB, et al. (2005) Transplantation of 2 partially HLA-matched umbilical cord blood units to enhance engraftment in adults with hematologic malignancy. Blood 105: 13431347.

72. Rocha V, Crotta A, Ruggeri A, Purtill D, Boudjedir K, et al. (2010) Double cord blood transplantation: extending the use of unrelated umbilical cord blood cells for patients with hematological diseases. Best Pract Res Clin Haematol 23: 223-229.

73. Delaney C, Gutman JA, Appelbaum FR (2009) Cord blood transplantation for haematological malignancies: conditioning regimens, double cord transplant and infectious complications. Br J Haematol 147: 207-216.

74. Kang HJ, Kho SH, Jang MK, Lee SH, Shin HY, et al. (2006) Early engraftment kinetics of two units cord blood transplantation. Bone Marrow Transplant 38: 197-201.

75. Brunstein CG, Barker JN, Weisdorf DJ, DeFor TE, Miller JS, et al. (2007) Umbilical cord blood transplantation after nonmyeloablative conditioning: impact on transplantation outcomes in 110 adults with hematologic disease. Blood 110: 3064-3070.

76. Ballen KK, Spitzer TR, Yeap BY, McAfee S, Dey BR, et al. (2007) Double unrelated reduced-intensity umbilical cord blood transplantation in adults. Biol Blood Marrow Transplant 13: 82-89.

77. Avery S, Shi W, Lubin M, Gonzales AM, Heller G, et al. (2011) Influence of infused cell dose and HLA match on engraftment after double-unit cord blood allografts. Blood 117: 3277-3285.

78. Poh SB, Hsiao LT, Yang CF, Chiou TJ, Chen PM. (2005) Fatal early-onset epstein-barr virus-associated posttransplantation lymphoproliferative disease after successful adult dual-unit umbilical cord blood transplantation. Biol Blood Marrow Transplant 11: 732-733

79. Barker JN, Weisdorf DJ, Wagner JE (2001) Creation of a double chimera afte the transplantation of umbilical-cord blood from two partially matched unrelated donors. N Engl J Med 344: 1870-1871.

80. De Lima M, St John LS, Wieder ED, Lee MS, McMannis J, et al. (2002) Doublechimaerism after transplantation of two human leucocyte antigen mismatched, unrelated cord blood units. Br J Haematol 119: 773-776.

81. Yen HJ, Chiou TJ, Hung GY, Chang CY, Hsieh MY, et al. (2008) Long-term mixed full-donor chimerism with dominance reversion after a double-unit cord blood transplant. Eur J Haematol 80: 366-367.

82. Arachchillage DR, Dalley CD, Reilly JT, Wilson G, Collins N, et al. (2010) Long-term dual donor derived haematopoietic reconstitution following double unrelated cord blood transplantation--single unit dominance is not always the case. Br J Haematol 149: 298-299.

83. Kang HJ, Yoo KH, Lee JW, Kim H, Lee SH, et al. (2010) Double umbilical cord blood transplantation for children and adolescents. Ann Hematol 89: 10351044.

84. Ramirez P, Wagner JE, Defor TE, Blazar BR, Verneris MR, et al. (2011) Factors predicting single-unit predominance after double umbilical cord blood transplantation. Bone Marrow Transplant.

85. Scaradavou A, Smith KM, Hawke R, Schaible A, Abboud M, et al. (2010) Cord blood units with low CD34+ cell viability have a low probability of engraftment after double unit transplantation. Biol Blood Marrow Transplant 16: 500-508.

86. Eldjerou LK, Chaudhury S, Baisre-de Leon A, He M, Arcila ME, et al. (2010) An in vivo model of double-unit cord blood transplantation that correlates with clinical engraftment. Blood 116: 3999-4006.

87. Gutman JA, Turtle CJ, Manley TJ, Heimfeld S, Bernstein ID, et al. (2010) Single-unit dominance after double-unit umbilical cord blood transplantation coincides with a specific CD8+ T-cell response against the nonengrafted unit. Blood 115: 757-765

88. Haspel RL, Kao G, Yeap BY, Cutler C, Soiffer RJ, et al. (2008) Preinfusion variables predict the predominant unit in the setting of reduced-intensity double cord blood transplantation. Bone Marrow Transplant 41: 523-529.

89. Verneris MR, Brunstein CG, Barker J, MacMillan ML, DeFor T, et al. (2009) Relapse risk after umbilical cord blood transplantation: enhanced graft-versusleukemia effect in recipients of 2 units. Blood 114: 4293-4299.

90. Moretta A, Andriolo G, Lisini D, Martinetti M, Pasi A, et al. (2012) In Vitro Evaluation of Graft-versus-Graft Alloreactivity as a Tool to Identify the Predominant Cord Blood Unit before Double Cord Blood Transplantation. Biol Blood Marrow Transplant.

91. Schellekens J, Rozemuller EH, Petersen EJ, van den Tweel JG, Verdonck LF, et al. (2008) Patients benefit from the addition of KIR repertoire data to the donor selection procedure for unrelated haematopoietic stem cell transplantation. Mol Immunol 45: 981-989.

92. Willemze R, Rodrigues CA, Labopin M, Sanz G, Michel G, et al. (2009) KIRligand incompatibility in the graft-versus-host direction improves outcomes after umbilical cord blood transplantation for acute leukemia. Leukemia 23 : 492-500. 
Citation: Jens G, Arwen S, Emma W, Jonas M, Michael U (2012) Mixed Chimerism after Allogeneic Stem Cell Transplantation - Focus on Double Cord Blood Transplantation. J Blood Disord Transfus S1:006. doi:10.4172/2155-9864.S1-006

Page 7 of 7

93. Remberger M, Svahn BM, Mattsson J, Ringden O (2004) Dose study of thymoglobulin during conditioning for unrelated donor allogeneic stem-cell transplantation. Transplantation 78: 122-127.
94. Okas M, Gertow J, Uzunel M, Karlsson H, Westgren M, et al. (2010) Clinical expansion of cord blood-derived T cells for use as donor lymphocyte infusion after cord blood transplantation. J Immunother 33: 96-105. 